\title{
Quantitative Series: Factors Analysis Effects of Government Regulation Number 46 the Year 2013 For SME's by Justice, Convenience, and Simplicity of Tax Aspects
}

\author{
${ }^{1}$ Aditya Halim Perdana Kusuma Putra, ${ }^{2}$ Aan Aswari, ${ }^{3}$ Muhammad Ya'arif Arifin, \\ ${ }^{4}$ Rina \\ ${ }^{1}$ STIM Lasharan Jaya, ${ }^{2,3}$ Universitas Muslim Indonesia, ${ }^{4}$ STIM-LPI \\ email: adityatrojhan@gmail.com
}

\begin{abstract}
In 2013 the business circle was struck by the new tax rules, namely Government Regulations PP No. 46, 2013 on taxation regulations among UKM (SME's) / Small Medium Enterprises but the strong allegations issued PP 46 of 2013 is because the potential tax revenue from the sector of UKM has not been explored to the fullest. By the required by the taxpayer related PP. No. 46 of 2013 uses several variables, namely taxes, taxes, taxes and tax benefits. The object of this research is the perpetrators of UKM (SMEs) in Makassar City who do 40 people using quantitative analysis and quantitative analysis. The result of this research indicates that the perception of justice tax has a significant effect as well as the most dominant variable affecting taxpayer compliance, taxability perception has a significant adverse impact on taxpayer compliance, tax perception simplicity has no significant impact, taxpayer's judgment is not valid in testing. The overall coefficient of determination contributes $26.5 \%$.
\end{abstract}

Keywords: tax justice, convenience of tax, simplicity of tax, tax benefit, taxpayer compliance

\section{INTRODUCTION}

In 2013 the business circle was struck by the new tax rules, namely Government Regulation no. 46, 2013 on taxation laws among SMEs ${ }^{1}$.The new tax regulation is claimed to facilitate tax payments by taxpayers in Indonesia, especially the primary target of this Government Regulation is among SMEs (Small and Medium Enterprises) ${ }^{2}$. In some socialisations by the Directorate General of Taxation, illustrations are often given that this regulation should be more acceptable to SMEs because previously taxpayers are charged $25 \%$ of net profit with a static calculation with a profit margin of $7 \%$. The above illustration certainly looks correct but provided that the net profit margin is $7 \%$. But what happens when the SME business has a profit margin of only $2 \%$, so this makes a lot of start-up companies

\footnotetext{
1 www.Minghadi.Com (2013) Pro Kontra (Peraturan Pemerintah) PP 46 Tahun 2013 / Sharing Ideas, Webpage .

2 ibid
} 
to be worried ${ }^{3}$. Because it has become common knowledge, the start-up has a reasonably long payback rate. If we simplify, most start-ups have to go through a period of loss for several years until they can make a profit.

Government Regulation no 46 of 2013 is driven more by the spirit to facilitate the Director General of Taxes in enforcing tax rules, especially for taxpayers who avoid obligations ${ }^{4}$. Tax as an obligation to surrender a portion of wealth to the State treasury due to a circumstance, event, and act which gives a specific position, but not a punishment, according to the rules established by the government and may be imposed, but there is no reciprocal service from the state directly, to foster general welfare ${ }^{5}$. In (UU. No. 17 Tahun 2000) explain that Tax is a compulsory contribution to a State which is owned by an individual or a coercive body under the Act, without obtaining direct remuneration and used for the State for the highest possible prosperity of the people. Other than that ${ }^{6}$. Taxpayer segmentation classified as tax subjects in PP 46 is very large, so it can provide opportunities for the community to contribute in the implementation of the state, as well as foster voluntary compliance in paying taxes ${ }^{7}$. Taxpayer compliance is a condition in which the taxpayer fulfil all tax obligations and exercises his taxation rights ${ }^{8}$. But on the other hand, PP no 46, in 2013 has a less precise spirit, especially regarding "fairness" where the amount of tax is determined in stages by the income of the taxpayer concerned ${ }^{9}$. There are two tax functions, namely budgetary function (state financial resources) and regulated functions. Type of Taxpayer compliance by ${ }^{10}$ is a formal Compliance is a situation where the taxpayer fulfills the obligation formally in accordance with the provisions of the tax law and material compliance is a condition where the taxpayer substantively / essentially perform all the requirements of taxation material that is in accordance with the content and.can also include formal agreement. For example, the time limit for the submission of Income Tax Form (SPT-PPh)

\footnotetext{
3 ibid

4 www.Pajak.Go.ld (2013) Pengukuhan Pengusaha Kena Pajak, Direktorat Jenderal Pajak, www.Pajak.Go.ld.

${ }^{5}$ Waluyo (2014) 'Perpajakan Indonesia', In Perpajakan Indonesia Edisi 11 Buku 1, p. 496.

${ }^{6}$ UU. No. 17 Tahun 2000 (2000) ‘Undang Undang No. 17 Tahun 2000 Tentang: Pajak', Sekretariat Negara. Jakarta.

7 www.Pajak.Go.Id (2013) Penyederhanaan Aturan Pajak Dalam Peraturan Pemerintah Nomor 46 Tahun 2013 / Direktorat Jenderal Pajak, Webpage Official Goverment.

${ }^{8}$ Herryanto, M. And Toly, A. A. (2013) 'Pengaruh Kesadaran Wajib Pajak, Kegiatan Sosialisasi Perpajakan, Dan Pemeriksaan Pajak Terhadap Penerimaan Pajak Penghasilan Di Kpp Pratama Surabaya Sawahan', Tax And Accounting Review, 1(1), pp. 125-133.

${ }_{9}$ www.Minghadi.Com (2013) Pro Kontra (Peraturan Pemerintah) Pp 46 Tahun 2013 / Sharing Ideas, webpage.

10 Yenni Mangoting (2000) 'Menyongsong Tax Reform 2001: Khusus Pajak Penghasilan', Jurnal Akuntansi Dan Keuangan, 2(2), pp. 116-126
} 
The plan to make the SME's as the focus or target of taxation has been heard since mid-2011 ${ }^{11}$. At that time data sources showed that MSME accounts for 61 per cent of Gross Domestic Product, but its contribution to total tax revenue is only 5 per cent. Therefore strong allegations that the issuance of PP 46 of 2013 is because the potential of tax revenues from the sector of UMKM has not been maximally explored ${ }^{12}$.

Judging from the concept of fairness in the taxation (equity principle), the imposition of Final Income Tax is not by justice because it does not reflect the ability to pay (ability to pay). Fair taxation is that the higher the income, the higher the taxes to be paid. This is called vertical equity or vertical equity ${ }^{13}$. In PP 46 of 2013 is also an adverse effect (disincentive) for growth start-up in Indonesia. The main reason is that many start-up innovations are "realtor services," such as re-sellers such as Bukalapak, Tokopedia, Lazada which mostly connect only sellers and buyers ${ }^{14}$. Where if calculated in turn can be seen as huge income, but with a small margin ${ }^{15},{ }^{16}$. The enactment of Government Regulation No. 46 of 2013 which requires entrepreneurs, including SME's, to be subject to a tax of one per cent $(0,5 \%)$ of total gross/gross income of each income. But in fact, until the end of 2017, the implementation of this policy was far from the fire because of up to last year from about 59 million perpetrators of SME's in Indonesia, who pay taxes only 397,000 SME's actors ${ }^{17}$.

In 2017, the Fiscal Policy Office (BKF) of the Ministry of Finance revealed that the review of changes in the calculation of Income Tax Rate (PPh) in the form of final tax rate or not, is still being discussed together with the Directorate General of Taxation (DGT), especially regarding the implementation of Government Regulation No. 46 year $2013^{18}$ in (Majalah UKM, 2014). Therefore, the occurrence of a lot of polemic in the midst of business actors, then Finance Minister Sri Mulyani proposed a revision related to PP. No. 46 the year 2013. A review of the Government Regulation by reducing the amount of tax payment from $1 \%$ to $0.5 \%{ }^{19}$. And now the regulation was applied from $1 \%$ to $0,5 \%$ at Juli 2018 . It aims not to burden business actors and create a win-win solution and the principle of "Fairness" by the government and also for the business actors themselves. Further in this background, for the simplicity of tax in PP. No. 46 the year 2013 as intended, the imposition

\footnotetext{
${ }^{11}$ Economy.Okezone.Com (2013) Pajak Umkm, Sederhana Tapi Tidak Adil, Online Newspaper.

12 ibid

${ }^{13}$ Ruston Tambunan (2013) Pajak Umkm, Sederhana Tapi Tidak Adil, Online Newspaper.

${ }^{14}$ William Henley (2018) Keadilan Dan Pajak Pedagang Di Medsos, Webpage Newspaper.

${ }^{15}$ www.Minghadi.Com (2013) Pro Kontra (Peraturan Pemerintah) PP 46 Tahun 2013 / Sharing Ideas,

Webpage .

${ }_{16}$ Majalah Ukm (2014) PP No.46 Tahun 2013 Tidak Adil Dan Tidak Pro Pengusaha Kecil,

17 ibid

${ }^{18}$ CNN Indonesia.com (2017) Pemerintah Masih Godok Perubahan Tarif Pph Final.

19 Www.Metrotvnews.Com (2018) Turunkan Tarif Pph Umkm, Sri Mulyani Usulkan Revisi Peraturan

Pemerintah No. 46 Tahun 2013, Online Newspaper.
} 
of the tax rate shall apply only to its turnover value of not more than IDR. 4.8 billion in one year, meaning that if the taxpayer has a turnover of more than IDR. 4.8 billion in one year, it shall be subject to the tax base by general provisions of Income Tax. The simplicity of the tax is that in completing the charge, payment can be done at the Bank or post office or using the e-billing system. For the simplicity of charge in the form of tax reporting, the taxpayer may report by himself no later than 20 days before the tax period expires, or the taxpayer is deemed to have published his tax based on the date of validation of his tax deposit. Therefore, this study led to the collecting of several previous research results that empirically stated that the understanding of PP. No. 46 the year 2013 has a positive and significant effect on taxpayer compliance in their tax reporting, as some researchers say $^{20,21,22,23,24}$ states that the perception of the simplicity of tax affects the satisfaction and compliance of taxpayers, states that the knowledge of tax utilization affect taxpayer satisfaction and respect ${ }^{25}$, Novandini and Hasana indicates that the judgment of tax utilization change taxpayer satisfaction and compliance, says that the perception of convenience affect taxpayer satisfaction and respect ${ }^{26}$. in the results of his study states that the tax justice has a significant effect on taxpayer compliance.

Objectively in this study is to test the dominant factor on implementation rather than Government Regulation no. 46 the year 2013 on taxpayer compliance of SME actors from the aspects of tax justice, ease of tax reporting, and simplicity in tax reporting.

\section{METHOD}

This study used a sample of 40 SMEs in Makassar City selected randomly from 15 districts ${ }^{27}$. Methods of data collection using questionnaires with scale measurement using Likert scale $(1$ = strongly disagree $/ \mathrm{STS}, 2$ = disagree $/ \mathrm{TS}, 3=$ less agree $/ \mathrm{KS}, 4$ = Agree

\footnotetext{
${ }^{20}$ Yasa (2015) 'Analisis Penerapan Peraturan Pemerintah No. 46 Terhadap Kepatuhan Wajib Pajak Pada Kantor Pelayanan Pajak Pratama Denpasar Timur', Jurnal Bisnis Dan Kewirausahaan, 11(1), pp. 70-80

21 Vina Rosella, K. (2015) 'Pengaruhpersepsi Atas Ppnomor 46 Tahun2013 Terhadap Kepatuhanwajib Pajak', Jurnal IImu \& Riset Akuntansi, 4(9)

22 Imaniati, Z. Z. (2016) 'Pengaruh Persepsi Wajib Pajak Tentang Penerapan PP No.46 Tahun 2013, Pemahaman Perpajakan, Dan Sanksi Perpajakan Terhadap Kepatuhan Wajib Pajak Usaha Mikro, Kecil, Dan Menengah Di Kota Yogyakarta', Jurnal Nominal, V(46).

${ }^{23}$ Carvallo, A. B. (2016) Pengaruh Penerapan Pp No. 46 Tahun 2013 Terhadap Tingkat Kepatuhan Wajib Pajak Badan Umkm (Studi Kasus Pada Kpp Pratama Bandung Cibeunying), Fakultas Ekonomi Universitas Widyatama.

24 Desintiani, L. (2017) 'Pengaruh Persepsi Keadilan Perpajakan, Kemudahan Perpajakan, Dan Kesederhanaan Perhitungan Pajak Terkait Pp No. 46 Tahun 2013 Terhadap Kepatuhan Wajib Pajak Pelaku Umkm (Survei Pada Wajib Pajak Di Kpp Pratama Jakarta Palmerah)

${ }^{25}$ Hasana, J. (2017) 'Persepsi Kemudahan Dan Kebermanfaatan Atas Penggunaan E-Filing Terhadap Kepatuhan Wajib Pajak Melalui Penggunaan E-Filing Sebagai Variabel Intervening'. Fe Umy

26 Vina Rosella, K. (2015) 'Pengaruhpersepsi Atas Ppnomor 46 Tahun2013 Terhadap Kepatuhanwajib Pajak', Jurnal Ilmu \& Riset Akuntansi, 4(9)

27 Putra, A. H. P. K., Said, S. And Hasan, S. (2017) 'Implication Of External And Internal Factors Of Mall Consumers In Indonesia To Impulsive Buying Behavior', International Journal Of Business Accounting And Management Issn, 2(4), pp. 1-10.
} 
/ $\mathrm{S}$ and 5 = strongly agree $/ \mathrm{SS})^{28}$. The analysis method using Explanatory factor analysis (EFA) with SPSS ver.24 analysis tool. The stages in quantitative testing in this study are through several stages ${ }^{29}$ as follows:

1. Bivariate Correlation

2. Partial Correlation

3. KMO Test (Kaiser Meyer Olkin)

4. MSA Test (Measure Sampling Adequacy)

5. Normality Test

\section{ANALYSIS AND DISCUSSION}

\section{a. Distribution of Frequency}

A total of 40 respondents of SMEs sampled in this study consisted of several categories of business types composed of 4 types of business of clothes/clothes, consisting of 6 kinds of fashion category, one business group engaged in the production of ready-toeat seasonings, and 1 for the type category of souvenirs. While involved in the type of business batik and equipment consists of 5 SMEs, 9 SMEs involved in the food business and 3 SMEs engaged in the kind of catering business, a group of companies involved in printing and 6 SMEs been been involved in handicrafts/handicraft. Further data on data of SME respondents will be described more detailed again based on the distribution table of respondents gender and age level of respondents. The distribution of respondents by sex and age as below.

Table 1. Frequency Distribution by Sex

\begin{tabular}{c|c|c}
\hline Gender & Frequency (Person) & Percentage (\%) \\
\hline Male & 19 & 47,5 \\
\hline Female & 21 & 52,5 \\
\hline Total & $\mathbf{4 0}$ & $\mathbf{1 0 0}$
\end{tabular}

Can be seen in table 4 above, that of 40 respondents, men as many as 19 people ( $47.5 \%)$ while women as many as 21 people (52.5\%). So it can be concluded that the dominant respondents are from among women.

Table 2. Frequency Distribution by Age

\begin{tabular}{c|c|c}
\hline Age & Frequency (Person) & Percentage (\%) \\
\hline $18-25$ Year & 10 & 25 \\
\hline
\end{tabular}

${ }^{28}$ Aditya HPK Putra (2016) 'Fans Vs Music Beneficiary At Music Industry In Indonesia In Seeing Through The Aspect Approach Of Marketing Mix', In Dileep Kumar, M., P.. (Ed.) 5th International Conference On Research Method In Management And Social Sciences. Makassar: 5th International Conference On Research Method In Management And Social Sciences (Icrmms-2016), pp. 104-112

${ }_{29}$ Aditya, H. P. (2012) 'Analisis Pengaruh Harga, Data Demografi, Promosi Terhadap Kecenderungan Pembelian Impulsif Dan Pengaruhnya Terhadap Budaya Konsumerisme Relatif Pada Konsumen Kfc Kota Makassar'. Tesis. 


\begin{tabular}{c|c|c}
\hline $26-33$ Year & 11 & 27,5 \\
\hline $34-41$ Year & 9 & 22,5 \\
\hline $42-49$ Year & 4 & 10 \\
\hline Up to 50 Year & 6 & 15 \\
\hline Total & $\mathbf{4 0}$ & $\mathbf{1 0 0}$ \\
\hline
\end{tabular}

It can be seen in table 5 above, that the age range of respondents who entered in the interval class 18 - 25 Years as many as 10 people (25\%), intervals 26-33 Years as many as 11 people (27.5), 34 - 41 Years as many as 9 people (22, 5\%), 42 - 49 Years as many as 4 people (10\%) and age 50 years and over as many as 6 people (15\%). The result of the translation of the frequency distribution table based on this age can be concluded that the dominant respondents are at the age interval of 18 - 33 years.

Perception Indicators of Tax Justice (X1)

Table 2. Taxpayer's Perception Item

\begin{tabular}{|c|l|c|c|c|c|c|c|c|c|c|c|}
\hline \multirow{2}{*}{ Code } & \multirow{2}{*}{ Item } & \multicolumn{10}{|c|}{ Frequency (person and \%) } \\
\cline { 3 - 14 } & & SS & $\%$ & S & $\%$ & KS & $\%$ & TS & $\%$ & STS & $\%$ \\
\hline X1.1 & General justice & 20 & 50 & 17 & 42.5 & 3 & 7.5 & 0 & 0 & 0 & 0 \\
\hline X1.2 & Tax Tariff Structure & 7 & 17.5 & 19 & 47.5 & 12 & 30 & 2 & 5 & 0 & 0 \\
\hline
\end{tabular}

For table 2. It can be seen that the variation of questionnaire distribution for $\mathrm{X} 1.1$ items dominantly centred on the answer Strongly Agree that as many as 20 people (50\%), while for item X1.2 focused on the answer agree that as many as 19 people (47.5\%).

Indicators of tax perception (X2)

Table 3. Consumer Expenditure Item

\begin{tabular}{|c|l|c|c|c|c|c|c|c|c|c|c|}
\hline \multirow{2}{*}{ Code } & \multirow{2}{*}{ Item } & \multicolumn{10}{|c|}{ Frequency (person and \%) } \\
\cline { 3 - 12 } & & SS & $\%$ & S & $\%$ & KS & $\%$ & TS & $\%$ & STS & $\%$ \\
\hline X2.1 & Tax Calculation & 12 & 30 & 19 & 47.5 & 7 & 17.5 & 2 & 5 & 0 & 0 \\
\hline X2.2 & Tax Deposit & 15 & 37.5 & 22 & 55 & 3 & 7.5 & 0 & 0 & 0 & 0 \\
\hline X2.3 & Tax Reporting & 10 & 25 & 22 & 55 & 6 & 15 & 2 & 5 & 0 & 0 \\
\hline X2.4 & Making of SKB & 12 & 30 & 23 & 57.5 & 4 & 10 & 1 & 2.5 & 0 & 0 \\
\hline
\end{tabular}

Can be seen in table 3 for the perception of ease of taxation with item X2.1 answer centred on the scale strongly agree that 19 people (47.5\%), for piece X2.2 response centred on the accepted level, i.e. 22 people (55\%), for item X2. Three answers focused on the agreed scale of 22 people (55\%), and for the item, X2.4, i.e. 23 people (57.5\%) centred on the level of the answer agreed

Perception Indicator Simplicity of tax (X3) 
Table 4. Simple Tax Perception Item

\begin{tabular}{|c|c|c|c|c|c|c|c|c|c|c|c|}
\hline \multirow{2}{*}{ Code } & \multirow{2}{*}{ Item } & \multicolumn{10}{|c|}{ Frequency (person and \%) } \\
\hline & & SS & $\%$ & $\mathbf{S}$ & $\%$ & $\mathrm{KS}$ & $\%$ & TS & $\%$ & STS & $\%$ \\
\hline X3.1 & Calculation & 12 & 30 & 18 & 45 & 10 & 25 & 0 & 0 & 0 & 0 \\
\hline X3.2 & Deposit & 9 & 22.5 & 19 & 47.5 & 11 & 27.5 & 1 & 2.5 & 0 & 0 \\
\hline X3.3 & Reporting & 19 & 47.5 & 19 & 47.5 & 2 & 5 & 0 & 0 & 0 & 0 \\
\hline X3.4 & Rectification of SPT & 10 & 25 & 22 & 55 & 8 & 20 & 0 & 0 & 0 & 0 \\
\hline
\end{tabular}

In table 4. It can be seen that the answer variation for item X3.1 centered on the agreed answer scale i.e. 18 people (45\%) although the answer less agree as many as 10 people $(25 \%)$ and who strongly agree 12 people $(30 \%)$, while for the X3.2 answer item centered on accepting 19 people (47.5\%) and most of them also answered in less favorable answers, ie as many as 11 people (27.5\%). For the X3.3 item, the dominant response centred on the agreed and strongly agreed that 19 people (47.5\%) in each category and for the article X3.4 dominant respondents answered on the accepted scale, i.e. 22 people (55\%).

Perception of Tax Benefit (X4)

Table 5. Taxpayer's Perception Item

\begin{tabular}{|c|c|c|c|c|c|c|c|c|c|c|c|}
\hline \multirow{2}{*}{ Code } & \multirow{2}{*}{ Item } & \multicolumn{10}{|c|}{ Frequency (person and \%) } \\
\hline & & SS & $\%$ & $\mathbf{S}$ & $\%$ & KS & $\%$ & TS & $\%$ & STS & $\%$ \\
\hline $\mathrm{X} 4.1$ & Budgetair $\mathrm{B}$ & 29 & 72.5 & 10 & 25 & 1 & 2.5 & 0 & 0 & 0 & 0 \\
\hline $\mathrm{X} 4$. & & 21 & 52.5 & 16 & 40 & 2 & 5 & 1 & 2.5 & 0 & 0 \\
\hline $\mathrm{X} 4$ & & 13 & 32 & 23 & 57.5 & 4 & 10 & 0 & 0 & 0 & 0 \\
\hline$X 4.4$ & Retribution Benefits & 23 & 57.5 & 16 & 40 & 1 & 2.5 & 0 & 0 & 0 & 0 \\
\hline
\end{tabular}

For table 5. The items of tax benefit perception, item X4.1 question centered on the answer scale strongly agree as many as 29 people ( $72.5 \%)$, item X4.2 on the answer scale strongly agree that 21 people (52.5\%), X4.3 items as much as 23 people (57.5\%) answered on the accepted level, and item X4.4 on the answer scale strongly agree that 23 people (57.5\%).

Taxpayer Compliance Indicators $(\mathrm{Y})$

Table 6. Taxpayer Compliance Item

\begin{tabular}{|c|l|c|c|c|c|c|c|c|c|c|c|}
\hline \multirow{2}{*}{ Code } & \multirow{2}{*}{ Item } & \multicolumn{8}{|c|}{ Frequency (Person and \%) } \\
\cline { 3 - 12 } & & SS & $\%$ & S & $\%$ & KS & $\%$ & TS & $\%$ & STS & $\%$ \\
\hline Y1 & Formal Compliance & 13 & 32.5 & 25 & 62.5 & 2 & 5 & 0 & 0 & 0 & 0 \\
\hline Y2 & Physic Compliance & 22 & 55 & 17 & 42.5 & 1 & 2.5 & 0 & 0 & 0 & 0 \\
\hline
\end{tabular}

For the dominant $Y 1$ item the respondent answered on the agreed answer scale, i.e. 25 people $(62.5 \%)$, and the $\mathrm{Y} 2$ object of respondents responded predominantly on a very agree to scale, i.e. 22 people (55\%). 


\section{b. Validity Test}

To see the correlation value can be known through the amount of Pearson correlation. The amount of correlation test between variables is as follows:

Table 7. Validity Test

\begin{tabular}{|c|c|c|c|}
\hline Item & Person Correlation & Significant Level & Result \\
\hline X1.1 & 0.663 & 0.000 & Valid \\
\hline X1.2 & 0.677 & 0.000 & Valid \\
\hline X2.1 & 0.522 & 0.000 & Valid \\
\hline X2.2 & 0.388 & 0.000 & Valid \\
\hline X2.3 & 0.623 & 0.000 & Valid \\
\hline X2.4 & 0.740 & 0.000 & Valid \\
\hline X3.1 & 0.350 & 0.027 & Valid \\
\hline X3.2 & 0.510 & 0.001 & Valid \\
\hline X3.4 & 0.597 & 0.000 & Valid \\
\hline X4.1 & 0.564 & 0.000 & Valid \\
\hline X4.2 & 0.778 & 0.000 & Valid \\
\hline X4.3 & 0.425 & 0.006 & Valid \\
\hline X4.4 & 0.494 & 0.001 & Valid \\
\hline Y1 & 0.578 & 0.000 & Valid \\
\hline Y2 & 0.743 & 0.000 & Valid \\
\hline \multicolumn{2}{|l}{ Mean } \\
\hline
\end{tabular}

From the table above It can be seen that the items X1.1 and X1.2 in forming tax perception justice variable is highly correlated that is $0.663(\mathrm{X} 1.1)$ and 0.677 (X1.2) the two items of the compilers variable perception of justice tax (X1) $0.00<0.05)$. For X2.1 items correlate normally in forming ease variable equal to 0.522 and stated significant $(0.001<0.05)$. Item X2.3 correlated high with value 0.623 and also significant $(0.00<0.05)$, similarly item X2.4 correlated high with correlation value 0.740 and significant $(0.00<0.05)$. Item X2.2 has enough correlation of 0.388 but its correlation is significant $(0.013<0.05)$. For X3.1 the items correlated sufficiently with the tax simplicity variables of 0.350 and stated significant $(0.027<0.05)$, Item X3.2 correlated to normal at 0.510 and significant $(0.001<0.05)$, item X3.4 also correlated to normal with 0.597 and significant $(0.00<0.05)$. For X4.1 items correlated normally with values of 0.564 and significant $(0.00<0.05), X 4.2$ items are highly correlated with values of 0.778 and significant $(0.00<0.05)$, X4.3 items are normally correlated with correlation values of 0.425 and significant $(0.006<0.005)$, item X4.4 is normal correlated with a value of 0.494 and significant $(0.001<0.05)$. For $Y 1$ items the correlation is normal with the correlation value of 0.578 and significant $(0.00<0.05)$, the $Y 2$ item is highly correlated with the correlation value of 0.743 and significant $(0.00<0.05)$.

\section{c. Reliability Test}

Reliability value can be seen based on Cronbach alpha value pursued above> 0.5 .

The data reliability test is as follows: 
Table 8. Reliability Test

\begin{tabular}{|c|c|l|}
\hline Item & Cronbach Alpha & Result \\
\hline X1.1 & 0.772 & Reliable \\
\hline X1.2 & 0.794 & Reliable \\
\hline X2.1 & 0.773 & Reliable \\
\hline X2.2 & 0.794 & Reliable \\
\hline X2.3 & 0.774 & Reliable \\
\hline X3.4 & 0.769 & Reliable \\
\hline X3.1 & 0.784 & Reliable \\
\hline X3.4 & 0.797 & Reliable \\
\hline X4.1 & 0.779 & Reliable \\
\hline X4.2 & 0.792 & Reliable \\
\hline X4.3 & 0.773 & Reliable \\
\hline X4.4 & 0.785 & Reliable \\
\hline Y1 & 0.783 & Reliable \\
\hline Y2 & 0.784 & Reliable \\
\hline Justice & 0.793 & Reliable \\
\hline Convenience & 0.733 & Reliable \\
\hline Simplicity & 0.763 & Reliable \\
\hline Benefits & 0.775 & Reliable \\
\hline Mean of Reliability Test & 0.775 & Reliable \\
\hline & \multicolumn{2}{|c}{} \\
\hline
\end{tabular}

From the table above can be seen that the overall value of Cronbach alpha item/indicator to taxpayer compliance variable is all above 0.5 with Cronbach alpha item value/indicator worth $0.740>0.5$. So it can be stated that all items/indicators are declared reliable, or Cronbach alpha value is at a high vulnerability inmates informing their respective variables.

\section{d. Normality Test}

Normality test is one of the classical assumption tests that must be fulfilled. Data is normally distributed if the value of Asymp Sig. $>0.05$. The normality test of this research is as follows:

Table 9. Normality Test

\begin{tabular}{llr}
\hline $\mathrm{N}$ & & 40 \\
\hline Normal Parameters & & Mean \\
\cline { 2 - 3 } & Std. Deviation & .0000000 \\
\hline Most Extreme Differences & Absolute & 1.00000000 \\
\cline { 2 - 3 } & Positive & .168 \\
\cline { 2 - 3 } & Negative & .168 \\
\hline Test Statistic & & -.109 \\
\hline Asymp. Sig. (2-tailed) & & .168 \\
\hline
\end{tabular}

In the normality test results obtained Asymp.Sig value of $1.243>0.05$ so that the data declared normal distributed and feasible to enter the next stage of testing the parametric.

\section{e. The determinant of Correlation Matrix Test}

The correlation matrix is stated between interrelated variables if the determinant is worth closer to the value 0 . The test determinant of correlation matrix as follows: 
Table 10. The determinant of Correlation Matrix Test

\begin{tabular}{|c|c|c|c|c|c|c|}
\hline & & Justice & Simplicity & Convenience & Benefits & $\begin{array}{c}\text { Taxpayer } \\
\text { Compliance }\end{array}$ \\
\hline \multirow{5}{*}{$\begin{array}{l}\text { Sig. (1- } \\
\text { tailed) }\end{array}$} & Justice & & .000 & .000 & .500 & .000 \\
\hline & Convenience & .000 & & .000 & .000 & .129 \\
\hline & Simplicity & .000 & .000 & & .000 & .235 \\
\hline & Benefits & .500 & .000 & .000 & & .000 \\
\hline & $\begin{array}{l}\text { Taxpayer } \\
\text { Compliance }\end{array}$ & .000 & .129 & .235 & .000 & \\
\hline
\end{tabular}

From table 10 on the determinant test, it can be seen that most of the indicators are interconnected, marked values that are zero or near zero. The taxability indicator with the determinant test value is 0.129 and the index of tax simplicity with the determinant value of 0.235 .

\section{f. Kaiser Mayer Olkin Measure of Sampling (KMO)}

Kaiser Meyer Olkin Measure of Sampling (KMO) is an index comparison of the distance between the correlation coefficient with partial correlation coefficient. If the sum of squares of partial correlation coefficients among all pairs of variables is small when compared to the number of squares of correlation coefficients, then it will produce KMO values close to 1 . KMO values are considered sufficient if more than 0.5 . The value of $K M O$ in the results of this study are as follows:

Table 11. KMO and Bartlett's Test

Kaiser-Meyer-Olkin Measure of Sampling Adequacy. .585 Bartlett's Test of Sphericity

\begin{tabular}{lr} 
Approx. Chi-Square & 173.953 \\
\hline df & 6 \\
\hline Sig. & .000 \\
\hline
\end{tabular}

In table 11 the Kaiser Meyer Olkin index value $(\mathrm{KMO})$ is 0.585 . Thus the $\mathrm{KMO}$ requirement qualifies as above from 0.5. While on the test results through Bartlett's Test Of Sphericity is equal to 173.953 with a significance value of $0.000<0.05$.

\section{g. Measures of Sampling Adequacy (MSA)}

Testing all correlation matrix (correlation between variables), as measured by Bartlett Test of Sphericity or (MSA). The MSA requirement value must be above 0.5 The MSA value on the interpretation of the results of this study is as follows:

Table 12. Measures Of Sampling Adequacy (MSA)

\begin{tabular}{rlr|r|r|r} 
& & & & \multicolumn{2}{c}{$\begin{array}{c}\text { Taxpayer } \\
\text { Compliance }\end{array}$} \\
\hline Anti-image & Justice & Simplicity & Convenience & Compe \\
Covariance & .814 & -.138 & -.183 & -.219 \\
\cline { 2 - 6 } & Convenience & -.138 & .769 & -.298 & .103 \\
\cline { 2 - 6 } & Simplicity & -.183 & -.298 & .751 & -.005 \\
\hline Taxpayer & -.219 & .103 & -.005 & .929 \\
Compliance & & & &
\end{tabular}




\begin{tabular}{rlr|r|r|r}
\hline Anti-image & Justice & $.619^{\mathrm{a}}$ & -.174 & -.234 & -.252 \\
\cline { 2 - 6 } Correlation & Convenience & -.174 & $.585^{\mathrm{a}}$ & -.392 & .122 \\
\cline { 2 - 6 } & Simplicity & -.234 & -.392 & $.601^{\mathrm{a}}$ & -.006 \\
\hline & Taxpayer & -.252 & .122 & -.006 & $.632^{\mathrm{a}}$ \\
\hline & & & & \\
\hline
\end{tabular}

In table 12 in column anti-image correlation can be interpreted as follows:

1. Indicator of tax fairness $(X 1)$ value of $M S A=0.619>0.5$. This means that the taxonly indicator has qualified for MSA

2. Taxability indicator $(\mathrm{X} 2)$ value of $M S A=0.585>0.5$. This means the tax-ease indicator has qualified MSA

3. The indicator of tax simplicity $(X 3)$ is the value of $M S A=0.601>0.5$. This means the tax-ease indicator has qualified MSA

4. The tax benefit indicator (X4) does not qualify for MSA, so it is not feasible and removed from the test variables.

5. Tax compliance indicator $(Y)$ the value of $M S A=0.632>0.5$. This means the tax compliance indicator meets the MSA requirements.

\section{h. Resume of Factor Analysis (Communalities)}

Communalities show the number of the variance in each variable to be taken into account. Commonalities are the relative variance in each variable taken into account by all components or factors. For primary component extraction, this is always equal to 1.0 for correlation analysis. Communalities extraction is the relative variance in each variable that is taken into account by the component. The value of Communalities on factor analysis of this study is as follows:

Table 13. Commonalities

\begin{tabular}{lr|r} 
& Initial & Extraction \\
\hline Justice & 1.000 & .631 \\
\hline Convenience & 1.000 & .696 \\
\hline Simplicity & 1.000 & .667 \\
\hline Taxpayer Compliance & 1.000 & .843 \\
\hline
\end{tabular}

From Table 19 above it can be concluded that the perception of tax justice can explain the value of factor at equal to 0.631 or $63.1 \%$, the opinion of taxability can demonstrate the importance of variance extraction factor of 0.696 or $69.9 \%$, the perception of simplicity of the tax with the value of variance factor of 0.667 or $66.7 \%$ tax can explain the importance of variance factor of 0843 or $84.3 \%$. While the perception of tax benefits is removed from the test because it does not qualify MSA. 


\section{i. Factors That Can Be Formed (Total Variance Explained)}

Table 14. Total Varian Explained

\begin{tabular}{rrrrrr} 
Component & \multicolumn{5}{c}{ Initial Eigenvalues } \\
Total & \% of Variance & Cumulative \% & Total \\
\hline 1 & 1.728 & 43.193 & 43.193 & 1.728 \\
\hline 2 & 1.109 & 27.727 & 70.920 & 1.109 \\
\hline 3 & .622 & 15.540 & 86.460 & \\
\hline 4 & .542 & 13.540 & 100.000 & \\
\hline
\end{tabular}

All percentage values of variance are above 1 (Initial Eigenvalues> 1) these four indicators when summed can explain the variable of $100 \%$.

\section{j. Loading Factors}

The loading factor value shows how much a variable correlates with the factor to be established. The loading factor value on statistical test result is as follows:

Table 19. Rotated Component Matrix

\begin{tabular}{lrrr} 
& 1 & Component & 2 \\
\hline Convenience & .828 & -.098 \\
\hline Simplicity & .812 & .094 \\
\hline Taxpayer Compliance &. .116 & .911 \\
\hline Justice & .542 & .581 \\
\hline
\end{tabular}

Table 19 above shows that in component 1 , the taxability perception of the correlation value is $0.828>0.5$, the perception of the simplicity of the correlation value tax is $0.812>0.5$. While taxpayer compliance is in component 2 with a correlation value of 0.911 and the perception of tax justice is also in component 2 with a correlation value of 0.581 . So it can be concluded the member of each factor is:

- $\quad$ Factor $1=\mathrm{X} 2$ and $\mathrm{X} 3$

- Factor $2=\mathrm{X} 1$ and $\mathrm{Y}$

The benefit variable is not visible and is not counted in this test because the variable is declared invalid in the previous MSA test.

\section{k. Hypothesis Test}

At this stage is in addition to factor analysis is also to determine whether the factors that have been tested and has a correlation as a construct factor whether significant or not, as well as to test the hypothesis. Here is the hypothesis test:

Table 20. Hypothesis Test

\begin{tabular}{l|r|r|r|r|r} 
& \multicolumn{2}{c|}{$\begin{array}{c}\text { Unstandardized Coefficients } \\
\text { Model }\end{array}$} & $\begin{array}{c}\text { Standardized } \\
\text { Coefficients } \\
\text { Beta }\end{array}$ & \multicolumn{1}{c|}{ t } & Sig. \\
\hline 1 & 4.083 & .292 & & 13.982 & .000 \\
\hline (Constant) & .225 & .043 & .269 & 5.178 & .000 \\
\hline
\end{tabular}




\begin{tabular}{l|r|r|r|r|r}
\hline Convenience & -.114 & .047 & -.134 & -2.438 & .015 \\
\hline Simplicity & .009 & .076 & .007 & .117 & .907 \\
\hline
\end{tabular}

In table 20 of the hypothesis test as a follow-up test rather than factor analysis can be expressed some test results as follows:

1. Perception of Tax Justice (X1) has a positive effect on taxpayer compliance (Y) with a $\beta$ coefficient value of 0.225 and significant (sig $0.000<0.05$ ).

2. Perception of Convenience of $\operatorname{Tax}(\mathrm{X} 2)$ hurts taxpayer compliance $(\mathrm{Y})$ with a $\beta$ coefficient value of -0.114 and significant (sig $0.015<0.05$ ).

3. Perceptions of Simplicity of Tax (X3) has no significant effect on taxpayer compliance $(\mathrm{Y})$. (sig 0.907>0.05).

The regression equation is as follows:

$$
\text { Taxpayer Compliance }=4.083+0.225+(-0.114)+0.009
$$

The results of statistical tests show that:

1. The perception of fairness of taxes have a positive and significant impact on tax compliance so it can be stated that $(\mathrm{H} 0=$ received, $\mathrm{H} 1=$ rejected $)$

2. The perception of taxability has a negative and significant effect on tax compliance, so it is stated that $(\mathrm{HO}=$ received, $\mathrm{H} 1=$ rejected $)$

3. The perception of the simplicity of the tax does not significantly affect taxpayer compliance so it can be stated that $(\mathrm{H} 0=$ rejected, $\mathrm{H} 1=$ accepted $)$

4. Perceptions of benefits declared invalid on testing MSA, so it is concluded that the perception of tax benefits do not have a significant effect $(\mathrm{HO}=$ rejected, $\mathrm{H} 1=$ accepted).

5. Perception of tax justice which is the most dominant dimension affect the compliance of taxpayers while the perception of benefits expressed invalid effect on taxpayer compliance. So it is stated that $(\mathrm{HO}=$ rejected, $\mathrm{H} 1=$ received $)$.

\section{The coefficient of Determinant Test $\left(R^{2}\right)$}

The coefficient of determination is the test result to see how much influence of the test variable to the dependent variable. The value of determination coefficient on the results of statistical tests are as follows:

Table 21. Coefficient of Determinant

Std. The error of the

\begin{tabular}{lr|r|r|r} 
Model & R & R Square & Adjusted R Square & \multicolumn{2}{c}{ Estimate } \\
\hline 1 & $.515^{\mathrm{a}}$ & .265 & .263 & .41613
\end{tabular}

In the test results, determination coefficient obtained the $R 2$ value of 0.265 which means that the perception of taxability, perceptions of tax justice, and the opinion of the simplicity 
of taxes contribute to taxpayer compliance is $26.5 \%$ while the remaining $73.5 \%$ taxpayer compliance is influenced by other factors.

\section{CONCLUSION}

\section{Tax fairness has a positive and significant impact on tax compliance}

Based on the results of statistical tests stated that Persepi fairness of taxes has a positive and significant effect on tax compliance. Fees are the most crucial factor for state finances in ensuring the sustainability of national development without being dependent on natural resources and foreign aid. Paying taxes is one of the obligations of citizens as regulated in Article 23A of the 1945 Constitution. In the results of data analysis test found that the respondents declared the application of PP tax no. 46 the year 2013, i.e. a fee of $1 \%$ of their total turnover is fair and appropriate. On the way PP. No. 46 the Year 2013 is a mandatory assessment for the government to the SMEs business, the principle of tax justice perceived by these respondents is also a reason why the SMEs are obedient to the PP. No. 46 such. Taxation expressed by a statement that every citizen should participate in government financing, to the extent possible proportionately according to his or her ability, by comparing the income he receives with the protection he enjoys from the state. The principle of justice in the laws of taxation legislation and the case of its implementation must be held firmly, even if the truth is very relative.

For tax collection not to cause any obstacles or resistance, the tax collection must meet the following requirements: (1) Tax collection must be fair (Terms of Justice). (2) Tax collection shall be by law (Juridical Terms). (3) Does not disturb the economy (Economic Terms). (4) Tax collection should be efficient (Terms of Financial). (5) The tax collection system should be simple. It should be understood that the tax compliance of SMEs players still needs to be improved again, some of which can be the cause are the first, the perpetrators of SMEs are dominated by domestic business actors. In a fair tax system, every taxpayer must pay tax in line with the benefits he enjoys from the government. This approach is called the revenue and expenditure approach. In terms of raising awareness and compliance with tax obligations, corporate and personal taxpayers also hope that the government's efforts in optimizing the potential of taxation based on social justice The concept of tax justice must also was applied to business people, especially those who run their business based on e-commerce so as an effort to administer justice to all taxpayers, tax levies in e-commerce are a must. Respondents' perceptions of fairness of PP tax application. No. 46 the Year 2013 is also the most dominant variable affecting taxpayer compliance because the tax justice is perceived would be useful as a feedback for the SMEs themselves. 


\section{The convenience of tax has a significant adverse effect on tax compliance}

The results of statistical tests state that the perception of taxability are having a significant impact on taxpayer compliance, but the effect is adverse or indirect. Provision of tax is mandatory as a citizen as stipulated in the Act, meaning that even though tax facilities have been adequate and made tax payments assessed easier but regarding the application of tax system PP. No. 46 the Year 2013, the perception of taxability is significant, but it does not affect indirectly.

Tax administration needs to be simplified to provide convenience and will be able to influence taxpayer compliance. The simplification of tax administration is applied by stipulating Government Regulation Number 46 the Year 2013. It is shown by the consideration was taken that it is necessary to give a treatment of the provisions concerning tax administration in the case of depositing and reporting the income tax payable. Taxpayers no longer need to submit SPT Period but with a condition to keep doing the calculation and the correct deposit.

\section{The simplicity of taxes has no significant effect on tax compliance}

The result of research stated that the perception of simplicity of charge does not have a substantial impact on taxpayer compliance so it can be noted that the research hypothesis is rejected. This indicates that the taxpayer of PPh UMKM after the implementation of the government regulation number 46 the year 2013 has not been aware of its tax obligation and suggested that the government's goal is to issue PP. No. The purpose of this program is to improve the understanding and awareness of SMEs on the achievement of their objectives. Rights of taxation obligations, then the socialization or extension of taxation and socialization of PP. 46 the year 2013 to increase the willingness of the UMKM Tax Payers in fulfilling their obligations.

Based on the observation in the field about the obstacles of the enactment of Government Regulation no. 46 indicates that there are many obstacles to the implementation of Government Regulation no. 46 namely the lack of taxpayer's understanding of the procedure of charging, calculation and on Government Regulation no. 46 itself. The number of obstacles felt by the taxpayer to be inconsistent with the purpose of the enactment of Government Regulation no. 46 namely: Convenience for the community in implementing tax obligations; Increase knowledge about tax benefits for the community; The creation of social control conditions in fulfilling the tax obligations. These constraints make PP 46 the year 2013 turns into complex complexity because it is inconvenient to taxpayers and burden Taxpayers because the taxpayer must reproduce his own SKB and pay with CNS sheet, thereby decreasing the value of compliance. 


\section{Tax benefits have no significant effect on tax compliance}

Benefit perception is not valid on MSA testing, so it is deleted in the further test, and it is concluded that the judgment of tax benefit has no significant effect. While in hypothesis 5 which states that the knowledge of tax benefits is the most dominant variable effect is not substantial results. Perceptions of tax justice which is the most dominant dimension affect taxpayer compliance.

\section{REFERENCE}

Aditya, H. P. (2012) 'Analisis Pengaruh Harga, Data Demografi, Promosi Terhadap Kecenderungan Pembelian Impulsif Dan Pengaruhnya Terhadap Budaya Konsumerisme Relatif Pada Konsumen Kfc Kota Makassar'. Tesis.

Aditya HPK Putra (2016) 'Fans Vs Music Beneficiary At Music Industry In Indonesia In Seeing Through The Aspect Approach Of Marketing Mix', In Dileep Kumar, M., P.. (Ed.) 5th International Conference On Research Method In Management And Social Sciences. Makassar: 5th International Conference On Research Method In Management And Social Sciences (Icrmms-2016), pp. 104-112.

Carvallo, A. B. (2016) Pengaruh Penerapan Pp No. 46 Tahun 2013 Terhadap Tingkat Kepatuhan Wajib Pajak Badan Umkm (Studi Kasus Pada Kpp Pratama Bandung Cibeunying), Fakultas Ekonomi Universitas Widyatama.

CNN Indonesia.Com (2017) Pemerintah Masih Godok Perubahan Tarif Pph Final.

Desintiani, L. (2017) 'Pengaruh Persepsi Keadilan Perpajakan, Kemudahan Perpajakan, Dan Kesederhanaan Perhitungan Pajak Terkait Pp No. 46 Tahun 2013 Terhadap Kepatuhan Wajib Pajak Pelaku Umkm (Survei Pada Wajib Pajak Di Kpp Pratama Jakarta Palmerah)'.

Economy.Okezone.Com (2013) Pajak Umkm, Sederhana Tapi Tidak Adil, Online Newspaper.

Hasana, J. (2017) 'Persepsi Kemudahan Dan Kebermanfaatan Atas Penggunaan E-Filing Terhadap Kepatuhan Wajib Pajak Melalui Penggunaan E-Filing Sebagai Variabel Intervening'. Fe Umy.

Herryanto, M. And Toly, A. A. (2013) 'Pengaruh Kesadaran Wajib Pajak, Kegiatan Sosialisasi Perpajakan, Dan Pemeriksaan Pajak Terhadap Penerimaan Pajak Penghasilan Di Kpp Pratama Surabaya Sawahan', Tax And Accounting Review, 1(1), pp. 125-133.

Imaniati, Z. Z. (2016) 'Pengaruh Persepsi Wajib Pajak Tentang Penerapan PP No.46 Tahun 
2013, Pemahaman Perpajakan, Dan Sanksi Perpajakan Terhadap Kepatuhan Wajib Pajak Usaha Mikro, Kecil, Dan Menengah Di Kota Yogyakarta', Jurnal Nominal, V(46).

Majalah Ukm (2014) Pp No.46 Tahun 2013 Tidak Adil Dan Tidak Pro Pengusaha Kecil.

Noviandini, N. C. (2012) 'Pengaruh Persepsi Kebermanfaatan, Persepsi Kemudahan Penggunaan, Dan Kepuasan Wajib Pajak Terhadap Penggunaan E-Filling Bagi Wajib Pajak Di Yogyakarta', Jurnal Nominal, 1(1).

Putra, A. H. P. K., Said, S. And Hasan, S. (2017) 'Implication Of External And Internal Factors Of Mall Consumers In Indonesia To Impulsive Buying Behavior', International Journal Of Business Accounting And Management Issn, 2(4), pp. 1-10.

Ruston Tambunan (2013) Pajak Umkm, Sederhana Tapi Tidak Adil, Online Newspaper.

UU. No. 17 Tahun 2000 (2000) 'Undang Undang No. 17 Tahun 2000 Tentang: Pajak', Sekretariat Negara. Jakarta.

Vina Rosella, K. (2015) 'Pengaruhpersepsi Atas Ppnomor 46 Tahun2013 Terhadap Kepatuhanwajib Pajak', Jurnal IImu \& Riset Akuntansi, 4(9).

Waluyo (2014) 'Perpajakan Indonesia', In Perpajakan Indonesia Edisi 11 Buku 1, p. 496.

William Henley (2018) Keadilan Dan Pajak Pedagang Di Medsos, Webpage Newspaper.

Www.Metrotvnews.Com (2018) Turunkan Tarif Pph Umkm, Sri Mulyani Usulkan Revisi Peraturan Pemerintah No. 46 Tahun 2013, Online Newspaper.

Www.Minghadi.Com (2013) Pro Kontra (Peraturan Pemerintah) PP 46 Tahun 2013 / Sharing Ideas, Webpage.

Www.Pajak.Go.Id (2013a) Pengukuhan Pengusaha Kena Pajak / Direktorat Jenderal Pajak, www.Pajak.Go.ld.

Www.Pajak.Go.Id (2013b) Penyederhanaan Aturan Pajak Dalam Peraturan Pemerintah Nomor 46 Tahun 2013 / Direktorat Jenderal Pajak, Webpage Official Goverment.

Yasa (2015) 'Analisis Penerapan Peraturan Pemerintah No. 46 Terhadap Kepatuhan Wajib Pajak Pada Kantor Pelayanan Pajak Pratama Denpasar Timur', Jurnal Bisnis Dan Kewirausahaan, 11(1), pp. 70-80.

Yenni Mangoting (2000) 'Menyongsong Tax Reform 2001: Khusus Pajak Penghasilan', Jurnal Akuntansi Dan Keuangan, 2(2), pp. 116-126. 